\title{
Simple Method for Determination of Deoxyribonucleic Acid Relatedness by Thermal Elution in Hydroxyapatite Microcolumns
}

\author{
MARC-ANDRÉ LACHANCE $\dagger$ \\ Unité de Physiologie Microbienne, Institut Pasteur, 75724 Paris Cedex 15, France
}

\begin{abstract}
A convenient method has been devised to chromatograph simultaneously numerous samples of reassociated deoxyribonucleic acid under thermoregulated conditions. Small amounts of hydroxyapatite $(0.2-\mathrm{ml}$ bed) were used, and the effluent volumes for separating single-stranded deoxyribonucleic acid from deoxyribonucleic acid duplexes were $1.5 \mathrm{ml}$ each. The method was comparable in reliability and reproducibility to other well-established techniques, but it combined improvements in ease of operation, in rapidity, and in simplicity, which are desirable in large taxonomic studies.
\end{abstract}

Deoxyribonucleic acid (DNA)-DNA reassociation has found widespread use in microbial taxonomy as a measurement of genetic relatedness. Several methods allowing thermal elution are available. The liquid reassociation technique, wherein hydroxyapatite adsorption allows the separation of DNA duplexes from their single-stranded counterpart, is considered the method of choice, especially since the advent of the batch method of Brenner and collaborators (1). For processing very large numbers of samples, which is often necessary in microbial phylogenetic studies, many workers prefer the use of DNA adsorbed onto nitrocellulose membranes (4), although this approach presents several pitfalls (7).

The batch method (1) offers advantages of reproducibility; furthermore, it has been found to be preferable to analogous column chromatographic methods, mainly because of the difficulties of controlling the temperature inside jacketed columns. The batch method has limitations. Transfer of tubes heated to a defined temperature from a thermoregulated bath to a heated centrifuge rotor is not without inconvenience, especially at higher temperatures (e.g. $95^{\circ} \mathrm{C}$ ). Elution by centrifugation is somewhat less efficient than column elution, and consequently the volumes of elution buffers are unnecessarily large. Considerable amounts of rather dilute radioactive effluents are usually obtained.

I describe here a simple, inexpensive method (involving small amounts of hydroxyapatite and elution buffers) of resolving DNA fractions in numerous samples in self-levelling microcolumns that are immersible in a thermoregulated ethylene glycol bath.

† Present address: Department of Plant Sciences, University of Western Ontario, London, Ontario N6A 5B7, Canada.

\section{MATERIALS AND METHODS}

Bacterial strains. Axenic cultures of cyanobacteria PCC 6303 and PCC 7415 (41.8 mol\% guanine plus cytosine $[G+C][6])$ were obtained from the Pasteur Culture Collection (Institut Pasteur, Paris) and were grown as described previously (11). Centrifuged cells were stored frozen until needed.

Extraction of DNA. Preparations of sheared DNA were obtained as recommended by Herdman et al. (6), who adapted the method of Britten et al. (2) to cyanobacteria. A yield of $0.2 \mathrm{mg}$ of DNA per $\mathrm{g}$ of wet biomass was obtained. The concentration and purity of each DNA solution were assessed by ultraviolet spectrophotometry. A conversion factor of 22 absorbance units $(260 \mathrm{~nm})$ per $\mathrm{mg}$ of DNA per ml of solution was determined empirically. DNA preparations were considered satisfactory when they exhibited ratios of absorbance at $260 \mathrm{~nm}$ to that at $280 \mathrm{~nm}$ of 1.9 .

Preparation of hydroxyapatite. Hydroxyapatite was prepared by a modification of the method of Siegelman et al. (10). Dipotassium phosphate (trihydrate, $1.4 \mathrm{~kg}$ ) and calcium chloride (dihydrate, $0.9 \mathrm{~kg}$ ) were dissolved separately, each in 3 liters of distilled water. Some of the calcium chloride solution (ca. 500 $\mathrm{ml}$ ) was stirred magnetically in a large container, and the two solutions were added to the container dropwise. The rate was such that the mixing was complete after 6 to $8 \mathrm{~h}$. The $\mathrm{pH}$ of the stirred slurry was then adjusted to 11 with potassium hydroxide and was periodically brought up to 9 until it stabilized to a value above 8 . The suspension was brought to neutrality by adding monopotassium phosphate, and it was left to settle. The supernatant was discarded and the hydroxyapatite was stored in the cold over chloroform. Before each use, the crystals were suspended in the appropriate buffer, and the resultant suspension was brought to a boil.

Radioiodination of DNA. The DNA preparations were radioactively labelled in vitro by the reaction of Cummerford (3), where iodine in the oxidized form reacts to produce a 5-iodocytosyl derivative of DNA. The reaction mixture proposed by Scherberg and Refetoff (9) was modified as follows: it contained $50 \mu \mathrm{g}$ of 
DNA per $\mathrm{ml}$ (denatured in distilled water for $2 \mathrm{~min}$ at $100^{\circ} \mathrm{C}$ ), $0.1 \mathrm{M}$ sodium acetate buffer ( $\mathrm{pH} 5.0$ ), $15 \mu \mathrm{M}$ potassium iodide, $100 \mu \mathrm{M}$ thallium trichloride (anhydrous), and $2 \mathrm{mCi}$ of $\mathrm{Na}^{125} \mathrm{I}$ per $\mathrm{ml}$ (Commissariat à l'Énergie Atomique, Saclay, France).

After heating the mixture at $60^{\circ} \mathrm{C}$ for $30 \mathrm{~min}$, each DNA solution was applied to a small column (a Pasteur pipette) of hydroxyapatite (equilibrated with $0.014 \mathrm{M}$ sodium phosphate, $\mathrm{pH} 6.8[\mathrm{~PB}]$ ), washed with equilibration buffer to remove free radioactivity, and eluted with $0.48 \mathrm{M} \mathrm{PB}$. After diluting the eluate to a $\mathrm{PB}$ concentration of $0.14 \mathrm{M}$, it was heated for $3 \mathrm{~min}$ at $100^{\circ} \mathrm{C}$ and was passed over a hydroxyapatite column (described below) equilibrated with $0.14 \mathrm{M} \mathrm{PB}$ containing $0.1 \%$ sodium dodecyl sulfate at $60^{\circ} \mathrm{C}$. The column was then washed with a small volume of this buffer. This last step left in the column essentially all materials that would appear double stranded at the onset of a renaturation experiment.

The eluate was dialyzed against the buffer recommended by Orosz and Wetmur (8) at $60^{\circ} \mathrm{C}$ for $20 \mathrm{~h}$. It was then readsorbed onto hydroxyapatite $(0.014 \mathrm{M}$ PB), washed, and eluted with $0.48 \mathrm{M}$ PB. This last step eliminated any uncombined or unstably combined iodine.

The DNA solution was then diluted to a relative activity of $2 \times 10^{6} \mathrm{cpm} / \mathrm{ml}$ and stored over chloroform in the cold. Specific activities of 3.4 and $3.0 \mu \mathrm{Ci} / \mu \mathrm{g}$ were obtained for the DNAs of strains PCC 6303 and PCC 7415, respectively, equivalent to about $5 \times 10^{6}$ $\mathrm{cpm} / \mu \mathrm{g}$ in a Nuclear Enterprises NE 1600 gamma counter.

Renaturation of DNA. For the renaturation of DNA, sealed reaction tubes, containing about 40,000 cpm of labeled DNA and $30 \mu \mathrm{g}$ of unlabeled DNA (total volume $=$ ca. $0.2 \mathrm{ml}$ ) in $0.28 \mathrm{M} \mathrm{PB}$, were prepared for each test. Denaturation was obtained by heating for $5 \mathrm{~min}$ at $105^{\circ} \mathrm{C}$, and the mixtures were incubated at $58^{\circ} \mathrm{C}$ for renaturation to occur.

Separation of DNA by the batch method. DNA was separated by the batch method (1) as follows. Solutions of renatured DNA were diluted to $10 \mathrm{ml}$ with $0.14 \mathrm{M} \mathrm{PB}$ containing $0.1 \%$ sodium dodecyl sulfate and were mixed in 40-ml centrifuge tubes with 1.5 $\mathrm{g}$ of hydroxyapatite equilibrated with the same buffer. The solutions were then heated to $60^{\circ} \mathrm{C}$ and were centrifuged at this temperature. The supernatants were collected, and the adsorbant was washed twice with equilibration buffer at $60^{\circ} \mathrm{C}$. These three combined washes contained at least $98 \%$ of the radioactivity elutable under these conditions. The doublestranded fraction was then eluted with $10-\mathrm{ml}$ washes of $0.14 \mathrm{~PB}$, at increasing temperatures, to obtain a denaturation curve. When only a total count of the double-stranded DNA was desired, the pellets were dissolved in dilute $\mathrm{HCl}$ (ca. $4 \mathrm{M}$ ). Samples of each fraction were counted in a gamma counter.

Separation of DNA on microcolumns. The microcolumns are illustrated in Fig. 1 . Up to 12 microcolumns were placed in a tube rack, and the hydroxyapatite was poured into the columns to form a bed of about $0.2 \mathrm{ml}$. After equilibration with $0.14 \mathrm{M}$ PB and sodium dodecyl sulfate, the siphon portions were placed in hemolysis tubes (11 by $75 \mathrm{~mm}$ ), and the rack was plunged into a thermoregulated ethylene glycol bath. The DNA solutions were diluted with one volume of distilled water, brought to $60^{\circ} \mathrm{C}$, and pipetted into the columns. When the liquid level was close to the bed surface, portions of elution buffer $(0.5 \mathrm{ml})$ were added. Unless otherwise indicated, two successive washes were performed. Residual adsorbed materials (double-stranded DNA) were then eluted (see Results) into clean tubes. Tubes containing each eluted fraction were dipped in water to rinse ethylene glycol and were blotted over tissue paper; radioactivity was counted directly in these tubes.

\section{RESULTS}

The elution of single-stranded and doublestranded DNA fractions in a preparation allowed to reassociate to $50 \%$ binding (as determined by the batch method) is illustrated in Fig. 2. In the microcolumn method, over $98 \%$ of the unbound fraction has been eluted by the third fraction $(1.5 \mathrm{ml})$. The elution patterns were essentially analogous for preparations with high (over 90\%) or low (below 5\%) binding. A standard elution volume of $1.5 \mathrm{ml}$ with each buffer was therefore adopted.

Renatured DNA was also eluted at constant phosphate concentration $(0.14 \mathrm{M})$ with increasing temperatures. Figure 3 shows a typical thermal elution curve obtained with microcolumns in comparison to one obtained by the batch method (1). The slight decrease in observed $T_{m}(e)$ by the microcolumn method indicates either a more thorough elution of the DNA denatured at each temperature or a better concordance between the temperature inside the columns and that indicated by the reference thermometer.

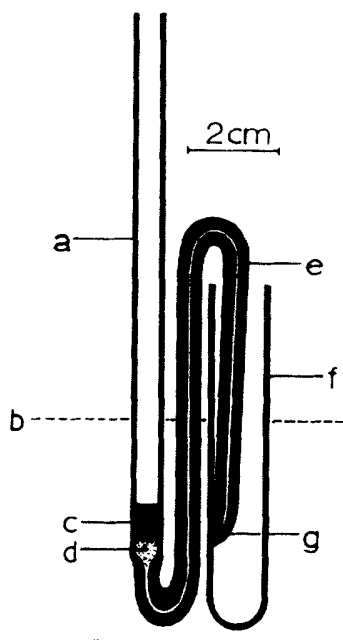

FIG. 1. Diagram of a microcolumn. (a) Tubing, 0.5 $\mathrm{cm}$ inside diameter; (b) glycol level in bath; (c) hy. droxyapatite bed; (d) glass wool; (e) tubing, 1-mm inside diameter; ( $f$ ) hemolysis tube (11 by $75 \mathrm{~mm})$; $(\mathrm{g})$ effluent outlet. 


\section{DISCUSSION}

The binding and elution efficiency of the microcolumns under the conditions described here is dependent on the quality of the hydroxyapatite used. The absorbant prepared in the laboratory from reagent-grade compounds $(10)$ is markedly superior in flow rate and binding capacity to commercial preparations (the hydroxyapatite used here could bind over $3 \mathrm{mg}$ of DNA per g). Consequently, it is not obvious that in microcolumns, commercially available adsorbant could be substituted for laboratory-made material, especially if DNA with a lower specific activity is used. A bed volume of $0.2 \mathrm{ml}$, as is used here, should bind up to about $300 \mu \mathrm{g}$ of DNA.

Iodine labeling of DNA in vitro offers major advantages with organisms such as cyanobacteria. The growth rates of these organisms are relatively low, the organisms appear impermeable to most specific precursors of DNA (5), and their yield of DNA is poor. Moreover, one cannot overlook another advantage: the development of multichannel gamma counters in conjunction with radioimmunoassay techniques. The microcolumn method, by producing effluents of small volumes, permits direct counting of the eluted fractions in multichannel gamma counters. Alternatively, it is possible to concentrate large effluents by trichloroacetic acid precipitation and collection of the insoluble DNA on filter membranes. This technique is cumbersome and costly if large numbers of samples are processed.

I routinely processed 12 samples simultaneously by the microcolumn method in about 30 min for simple separations and in about $90 \mathrm{~min}$

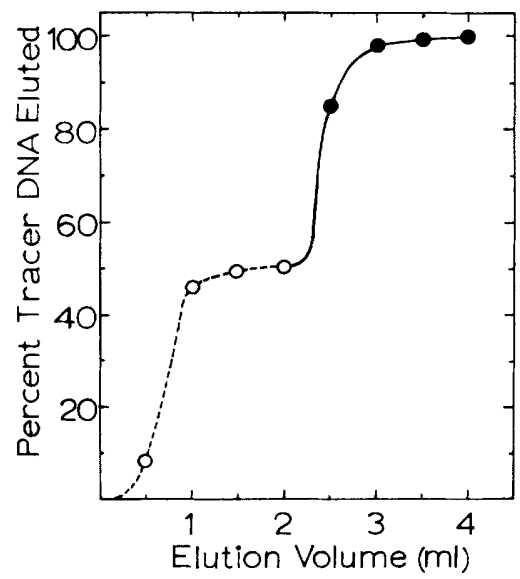

FIG. 2. Elution profile of DNA from strain PCC 6303 reassociated to $50 \%$ binding. Single-stranded DNA (O) was eluted with 0.14 M PB-0.1\% sodium dodecyl sulfate at $60^{\circ} \mathrm{C}$. Duplex DNA (O) was eluted with $0.48 \mathrm{MPB}$.

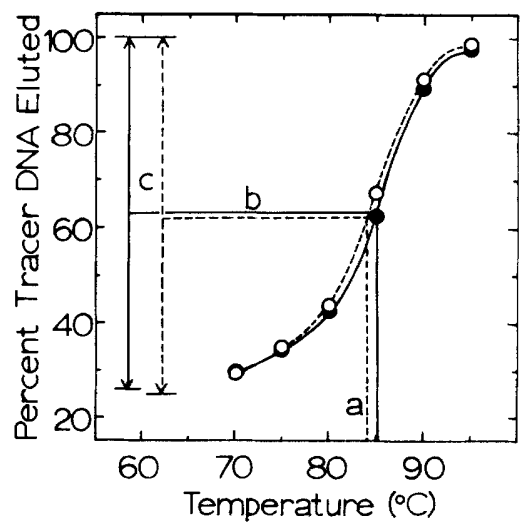

FIG. 3. Thermal elution profiles of DNA from strain PCC 7415 reassociated to $75 \%$ binding. Single-

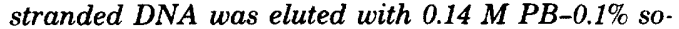
dium dodecyl sulfate, and duplex DNA was progressively denatured and eluted with $0.14 M P B$ at increasing temperatures. Each fraction represents two 0.5-ml washes on microcolumns (O), or one 10-ml wash by the batch (1) method (-) (see text for details). $T_{\mathrm{m}}(e)$ was determined graphically as the temperature (a) at which half (b) of the renatured DNA (c) was eluted.

for thermal elution of the duplex DNA. A thermoregulated centrifuge is not required.

Some laboratories achieve similar results by running straight columns through the bottom of a thermoregulated bath. The disadvantages of such a system are obvious.

\section{ACKNOWLEDGMENTS}

I acknowledge the awarding of a post-doctoral fellowship by the Direction Générale de l'Enseignement Supérieur, Ministère de l'Éducation, Québec. This research was supported by the Centre National de la Recherche Scientifique (EPA 398).

Thanks are extended to R. Y. Stanier, G. Cohen-Bazire, and D. J. Brenner for critically reading the manuscript and to M. Herdman, M. Popoff, and P. Pradelles for their expert advice. The help of F. Casero, T. Coursin, and R. Rippka in growing the cultures used in this work is gratefully acknowledged. I am grateful to A. Simon for skillfully executing the glasswork

\section{REPRINT REQUESTS}

Address reprint requests to: Dr. Marc-André Lachance, Department of Plant Sciences, University of Western Ontario, London, Ontario N6A 5B7, Canada.

\section{LITERATURE CITED}

1. Brenner, D. J., G. R. Fanning, A. Rake, and K. E. Johnson. 1969. A batch procedure for the thermal elution of DNA from hydroxyapatite. Anal. Biochem. 28:447-459.

2. Britten, R. J., M. Pavitch, and J. Smith. 1968. A new method for DNA purification. Carnegie Inst. Washington 68:400-402.

3. Cummerford, S. L. 1971. Iodination of nucleic acids in vitro. Biochemistry 10: 1993-1999.

4. Denhardt, D. T. 1966. A membrane filter technique for 
the detection of complementary DNA. Biochem. Biophys. Res. Commun. 23:641-646.

5. Glazer, V. M., M. A. Al-Nuri, V. V. Groshev, and S. V. Shestakov.1973. The labeling of nucleic acids by radioactive precursors in the blue-green algae Anacystis nidulans and Synechocystis aquatilis Sauv. Arch. Mikrobiol. 92:217-226.

6. Herdman, M., M. Janvier, J. B. Waterbury, R Rippka, R. Y. Stanier, and M. Mandel. 1979. Deoxyribonucleic acid composition of cyanobacteria. J. Gen Microbiol. 111:63-71.

7. Moore, R. L. 1974. Nucleic acid reassociation as a guide to genetic relatedness among bacteria. Curr. Top. Microbiol. Immunol. 64:105-128.
8. Orosz, J. M., and J. G. Wetmur. 1974. In vitro iodination of DNA. Maximizing iodination while minimizing degradation; use of buoyant density shifts for DNADNA hybrid isolation. Biochemistry 13:5467-5473.

9. Scherberg, N. H., and S. Refetoff. 1974. The radioiodination of ribopolymers for use in hybridizational and molecular analyses. J. Biol. Chem. 249:2143-2150.

10. Siegelman, H. W., G. A. Wieczorek, and B. C. Turner. 1965. Preparation of calcium phosphate for protein chromatography. Anal. Biochem. 13:402-404.

11. Stanier, R. Y., R. Kunisawa, M. Mandel, and G. Cohen-Bazire. 1971. Purification and properties of unicellular blue-green algae (Order Chroococcales). Bacteriol. Rev. 35:171-205. 